\title{
The Didactic Culture in the Faculty Performance in Higher Education: The Case of a Business School in Brazil
}

\author{
Carlos Augusto Candêo Fontanini \\ Pontifical Catholic University of Parana, Paraná, Brazil \\ Email:candeo.fontanini@gmail.com
}

How to cite this paper: Fontanini, C. A. C. (2017). The Didactic Culture in the Faculty Performance in Higher Education: The Case of a Business School in Brazil. Creative Education, 8, 1236-1259. https://doi.org/10.4236/ce.2017.88088

Received: April 18, 2017

Accepted: July 8, 2017

Published: July 11, 2017

Copyright $\odot 2017$ by author and Scientific Research Publishing Inc. This work is licensed under the Creative Commons Attribution-Non Commercial International License (CC BY-NC 4.0). http://creativecommons.org/licenses/by-nc/4.0/ (c) (i) \& Open Access

\begin{abstract}
The objective of this study was to analyze how Didactic Culture influences the faculty performance in a business administration program. In order to achieve that goal, it was necessary to create the concept of Didactic Culture. The instrument used for data collection was the in-depth interview. The research problem: How does didactic culture influence teacher performance in a business administration program? Content analysis was used for the processing of information. The population chosen to participate in this research was the faculty of the business administration program of the Business School of a large private higher education institution in Brazil. Fourteen professors were interviewed. The results of this research reveal that the didactic culture influences the teaching performance of professors in business administration programs as they develop and implement activities related to the improvement of the teaching and learning process.
\end{abstract}

\section{Keywords}

Didactic Culture, Pedagogical Training, Professors of Business

Administration Programs, Pedagogical Knowledge

\section{Introduction}

In order to train and develop professors for the improvement of the educational process and the quality of students' education, the teaching career has been the focus of studies in Brazil (Juliatto, 2013, Pimenta \& Anastasiou, 2012) since the end of the 20th century and beginning of the 21st century. Changes in the social, economic, political and cultural context have been taken into account.

We believe that the process of "teacher training", according to the United Nations Educational Scientific and Cultural Organization (Unesco) definition, "im- 
plies the acquisition of knowledge, attitudes, skills and behaviors closely associated with the professional field" (Imbernón, 1994: p. 13). Unesco also argues that the permanent formation of teachers is an educational process that aims at the revision and renewal of previously acquired knowledge, attitudes and skills, which are determined by the need for updating due to social, technological and scientific transformations. Because of the Unesco text, teacher training should provide the instruments that allow teachers to achieve greater autonomy and maturity to develop their profession to the fullest extent (Imbernón, 1994: p. 17; 39).

Considering all the above, refresher courses for teachers, especially in their conception of knowledge and the world, have strategic importance in our days. In fact, the effectiveness of higher education institutions should also be associated with the result of the quality of teaching performance for teaching and research (Díaz-Méndez \& Gummesson, 2012; Robinson \& Hope, 2013; Zeichner, Payne, \& Brayko, 2015). The future will depend on our ability to educate the young, to transform them into the creators and entrepreneurs of tomorrow (Halévy, 2008).

The pedagogical practice in higher education indicates the need for a formative process that conveys meaning and relevance, both for teachers and for students.

The need for a consistent pedagogical training that contributes to their teaching practice has been the challenge for university professors, especially in business administration programs, as poorly trained teachers will negatively impact their students' training (Pfeffer \& Fong, 2002).

It is well known that in the field of administration, faculty formation with a pedagogical vision has not been a fact, except on the initiative of the teacher himself. Systematically, there are a few actions and the trial-and-error approach acquired over the years. The construction of an identity for teachers of business administration programs in which a consistent pedagogical training is the focus is perhaps the greatest challenge of the teaching career.

The objective of this study was to analyze how Didactic Culture influences the faculty performance in a business administration program.

\section{Literature Review}

Much has been written about the teaching profession, according to Tardif and Lessard (2009), Altet (1994), however, in his studies mainly refers to those professionals who work at the initial levels of education. There is lack of studies on those teachers are active in higher education. Similarly, it happens in reference to studies that deepen in pedagogical issues and career development.

Teachers start their careers in higher education as if they were qualified for it, without any specific training, even in short courses. Even not being prepared, they face dozens of students, taking with them the experience gained during the college years or in their day to day professional life. They believe that this is enough to, at least, start their teaching life (Timpson \& Bendel-Simso, 1996). It 
is a common situation not only in business-related programs, but in all others that are not specific education programs. The pedagogical knowledge required for the teaching task for these teachers over a given period of time can be summarized in their professional experience and in their college degree. Also, they do not have much else to present.

Gauthier et al. (1997) describe as conceptual blindness certain preconceived ideas about teaching. For example, content knowledge, talent, common sense, intuition, and experience.

In the context of business, it is very common to find teachers who consider themselves qualified to teach by knowing the content or because they have the talent. This situation prevents them from seeking a more adequate training, or the pedagogical knowledge that contribute significantly to their performance inside and outside the classroom.

The expression "non-teacher teachers" is used for those who do not have specific or pedagogical training for the practice of teaching. These teachers do not have a degree in education.

For the teacher of the administration program, the repertoire of knowledge necessary for him to perform effectively consists of some main elements, that is, it is related to the specific knowledge he has about the program content, professional and teaching experience, how to conduct classes, how to prepare them, how to interact with students, how to stimulate them, and so on.

For the teacher of the administration program, the repertoire of knowledge necessary for him to perform effectively consists of some main elements, i.e., it is related to the specific knowledge he has about the program content, his professional and teaching experience, class planning and instruction, the relationship with students, how to motivate them, among others.

Several published studies, such as Handal, Wood, and Muchatuta (2011), Cochran-Smith (2005), Hanushek (2002), Anderson and Miller (1997), Reid (2011), Pennings et al. (2014) were developed, and still are, to unveil more elements on the teacher and student relationship. Part of these studies consists of studies between the student's performance and the practices used by the teacher in the classroom.

\section{Teacher Training for Business Administration Programs}

The role of the teacher and his educational commitment, which is social in nature, lead him to plan not only the impact of his teaching on the lives of students, but also the improvement of society. Therefore, quality of teaching is the most critical factor that interferes with student learning (Chong, 2014).

Classroom activity is only one of the complex aspects of the teaching profession in higher education. In order to teach, the teacher has a number of other activities to be accomplished. Some of these tasks include the planning and preparation of classes, corrections of tests, and other classroom activities, which make up evaluative activities, are present in the teacher's daily life (Philipp \& Kunter, 2013). 
Regarding student learning, the perceptions they have of a good teaching environment, which is pleasant, with a feeling of acceptance by teachers and other students, influences the deepening of the studied subjects. They will be more motivated to study.

However, when there is a poor perception about a particular teaching environment, in which the teacher is not able to adequately convey the contents, he becomes only a content transmitter, and as a result, the students are influenced in a negative way. This condition leads them to deal with their studies in a superficial way, which will result in low achievement and low scoring students (Lizzio, Wilson, \& Simons, 2002; Handal, Wood, \& Muchatuta, 2011; Duarte, 2013; Mitchell \& Bradshaw, 2013).

Chia (1996) criticizes the traditional methods of teaching business management by considering them to be of little use, as they strongly contribute to a reductionist thinking of the teacher, especially of how to deal with complex issues. In general, they are focused without a deepening and an adequate way of working with the program content.

The results of a study presented by Meyers (2012) show, at first, that teachers of a business school, a public university in the United States, were evaluated by their peers. Initially, the focal group technique was used with a sample of six teachers, three females and three males. From this sample, some of them were starting their activities as teachers in higher education and the others already had considerable teaching experience.

All teachers were asked about the importance of evaluating different factors that qualified the teaching in programs in the business area that could influence the performance in the classroom. As a result, twelve factors were identified: 1st level of teacher preparation; 2nd clarity in explanations; 3rd deep knowledge of the discipline taught; 4 th teacher enthusiasm to teach discipline; 5th self-confidence; 6th professionalism; 7th sense of humor; 8th possibility of discussing research results during class; 9th how to motivate students to think; 10th means to make students comfortable to ask questions during class; 11th make easier the access to the teacher; And 12 the possibility for students to perform extra-class activities to improve learning.

With these results, the researcher applied a questionnaire with the twelve items collected in the first stage of the research to a group of professors of programs of the business area, during two international conferences, in a city of Florida and another in Las Vegas, Both in the United States. At this stage, the group of teachers was asked to evaluate, among the twelve factors presented, those that could be used by professors of business programs to help them make their teaching activities better and perceived as teacher quality from their peers' perspective. To do so, they should use a scale of 1 to 5 , in which one meant little important, and five, very important.

The most important variable considered by the respondents was the level of preparation of the teachers, followed by the deep knowledge of the subject content. The author, at the conclusion of the study, discusses the importance of 
preparing teachers for programs in the business area. Thus, it was possible to emphasize how this preparation influences the performance in the classroom, which resulted in high scoring students.

In a study entitled Good Practices in Undergraduate Education, Chickering and Gamson (1987), Chickering (1999), with the support of the American Association of Higher Education, report more than two years of research on apathetic students, illiterate graduates, low quality education, and many others disparagements of higher education. According to these same authors, there are neither enough carrots nor enough sticks to improve undergraduate education without the commitment and action of students and faculty members. Students and faculty members are the most precious resources for anyone who wants the improvement of undergraduate education.

Chickering and Gamson (1987), Chickering (1999) present seven principles based on research on good pedagogical practice in American colleges and universities: 1) Encourage student-teacher contact; 2) Encourage cooperation between students; 3) Encourage active learning; 4) Give students immediate feedback; 5) Emphasize time dedicated to each task; 6) Communicate with high expectations regarding results; and 7) Respect the various talents in the classroom and their learning pace. Considering all the above, some studies carried out on the pedagogical practice used by teachers from several business schools are presented inadequately for the effective learning of the future administrators (Vaara \& Fay, 2012; Pfeffer \& Fong, 2002, 2004; Starkey, Hatchuel, \& Tempest, 2004).

We must rethink the teacher training of business administration programs in order not to contribute or corroborate with what Shulman (1987) states:

I do not know where it fits the infamous aphorism written by George Bernard Shaw and that have plagued the teachers for nearly a century. "He who can, does. He who cannot, teaches". It is a calamitous insult to our profession, yet one readily repeated even by teachers (P. 4).

\section{The Didactic Culture of Teachers in Business Administration Programs}

The word culture comes from the idea of cultivation, from the process of plowing and developing the land (Morgan, 1996; Williams, 2000). With this initial idea, the term culture is used to define a set of practices, ways of thinking and acting, which are inherited and learned through the ages. "Culture typically refers to the pattern of development reflected in social systems of everyday knowledge, ideology, values, laws, and rituals" (Morgan, 1996: p. 116).

Culture is also used to refer to the degree of subtleness in belief and practices systems. It also means, more generally, what different groups of people worship, such as different lifestyles. Culture can also be a community of people and their interrelations (Solomon, 1992).

Different studies (Cavanagh \& Waugh, 2004; Cheng, 1993; Huberman, 2007) have shown that a rooted culture can lead to increased productivity, adaptability and flexibility for the educational institution. This is because teachers feel good 
about teaching at that institution. As it is known, the pleasant work environment can influence the improvement of assessment results made with students, which, consequently, increases the commitment of teachers (Feldman \& Paulsen, 1999).

The concept of didactic culture in this research was focused on an individual aspect, that is, to the extent that an individual can have his culture or learn another one. That is the sense we work on the subject, the culture of the individual and, in this specific case, the teacher in the business administration program.

This sense of individual culture, according to Williams (2000), refers to culture as active cultivation of the mind; it is possible to differentiate a wide range of meanings when we deal with culture.

However, nowadays, considering the connotation of the teacher's culture in an individualized way, business administration program teachers seem to be overwhelmed by the syndrome, "I teach the way I want it, the way I like it, and the way I learned it". This process was developed throughout their careers. It was adapted to other styles of teaching, by observing the experiences developed by other faculty members, or even by adopting practices learned during college years, developed by their teachers. Former teachers, in general, have been considered by new teachers, a kind of gurus of how to teach effective classes.

It is also important to remember that some teachers in business administration programs, even without having specific didactic training, end up performing better than those who, in one way or another, have undergone such training.

It is precisely at this point that didactic culture comes in. Is it what makes one teacher in business administration program more or less effective than another, in a situation that both have had or not pedagogical training to work as teachers in higher education?

By defining the concept of didactic culture, our objective was to create elements that support research, from a theoretical and practical point of view, and answer the research problem: How does didactic culture influence teacher performance in a business administration program?

Starting from the elaboration of the concept of didactic culture and considering teachers in business administration programs, since the concept can vary from program to program, we must keep in mind some points necessary for the success of the process of construction of a new concept.

We go back here to the definition of Morgan (1996) and Williams (2000), who introduce us the term culture as having origin in the idea of cultivation, the process of tilling and developing the land. Williams (2000) further defines culture as the active cultivation of the mind.

Based on these definitions and adopting them as a reference, we come to what we conceptualize as didactic culture.

We consider didactic culture the pedagogical knowledge cultivated by the teachers in business administration programs throughout their teaching career. Therefore, it is associated with the technical knowledge, acquired mainly during 
their academic training.

It aims at improving their teaching performance in the classroom and seeks to increase the student's learning process, enabling him to become a transforming agent of society.

The technical knowledge is acquired by the teacher in his training, bachelor's, master's or doctorate degrees. As for the pedagogical knowledge, it can be developed formally during a specific training, in this case, in a teacher education program, in retraining or even extension courses, carried out throughout the teaching career.

It is also possible to acquire pedagogical knowledge based on the observation of the processes adopted by former teachers, or through the exchange of experiences with co-workers, other teachers from the same institution of higher education.

\section{Methodology}

This research was characterized as a qualitative study. The population chosen to participate in this research was the faculty of the business administration program of the School of Business of a large private higher education institution in Brazil.

The faculty of the business school has a total of 96 professors; the business administration program has forty-six faculty members with degrees in several areas of knowledge.

The fourteen professors included in the sample graduated in business administration, hold masters and doctorate degrees also in business administration. They have been teaching in higher education institutions for more than eight years.

In this study, a non-probabilistic sample was used by judgment. All professors included have the same formation, masters and doctors in business administration, faculty members of the same institution of higher education.

In order to facilitate the registration and organization of the collected information, WebQDA-Qualitative Data Analysis software was used. This software was developed in a partnership between the company Esfera Crítica and the Center for Didactic Research and Technology in Training for Trainers, Department of Education, University of Aveiro, both from Portugal.

WebQDA is makes possible the analysis of qualitative data in a collaborative and distributed environment. With WebQDA, the researcher can edit, view, link and organize documents. At the same time, it is possible to create categories, code, control, filter, search, and query data in order to answer the questions that emerge during the investigation. WebQDA consists of the Source and Coding System.

Sources are broken down into internal sources, external sources, and notes. The encoding is structured in nodes, which are subdivided into tree nodes and free nodes.

Next, (Table 1) information with the name given to each teacher, time as a teacher in higher education, the current workload in the administration program 
Table 1. Research participants.

\begin{tabular}{|c|c|c|c|}
\hline \multicolumn{4}{|c|}{ RESEARCH PARTICIPANTS } \\
\hline Professor & $\begin{array}{c}\text { Time as a professor in higher } \\
\text { education (years) }\end{array}$ & $\begin{array}{l}\text { Current workload ADM } \\
\text { program/month }\end{array}$ & $\begin{array}{l}\text { Non-teaching } \\
\text { activities }\end{array}$ \\
\hline Leo & 9 & 40 & - \\
\hline 2 Andromeda & 12 & 40 & - \\
\hline Crux & 38 & 40 & Business Consultant \\
\hline $4 \quad$ Aries & 9 & 40 & - \\
\hline Aquila & 20 & 40 & Business Consultant \\
\hline 6 Phoenix & 17 & 40 & - \\
\hline 7 Draco & 8 & 12 & Business Consultant \\
\hline 8 Pegasus & 20 & 40 & - \\
\hline 9 Gemini & 13 & 40 & - \\
\hline 10 Sagittarius & 14 & 40 & - \\
\hline 11Capricornus & 9 & 12 & Business Consultant \\
\hline 12 Taurus & 17 & 40 & - \\
\hline 13 Pyxis & 19 & 40 & Business Consultant \\
\hline 14 Orion & 17 & 40 & - \\
\hline
\end{tabular}

Source: Research data.

and, if applicable, other non-teaching activities. ${ }^{1}$

The objective of this research was to analyze how didactic culture influences faculty performance in an administration program.

This study, which took place in a single environment, a private university and in a given program, was configured as a case study (Collis \& Hussey, 2005). The objective was to understand the dynamics within this higher education institution within the program under scrutiny.

The research instrument was the in-depth interview. The content analysis was used to interpret the information collected (Bardin, 2013).

In order to prepare the data collection instrument for this research, the in-depth interview using the semi-structured script (Seidman, 1998) was considered the framework of the categories that make up the professors' knowledge scope (Shulman, 1987).

Thus, in addition to the preparation of the data collection instrument, the definition of the categories that make up the professors' knowledge scope made possible to understand what the pedagogical knowledge is, which contributed fundamentally to the understanding of the didactic culture of the faculty in the business administration program.

\section{Results and Discussion}

In the following table, we have for each professor, with fictitious constellation

${ }^{1}$ For the fictitious names, the names of fourteen constellations were used. According to the International Astronomical Union (CLAVIA, 2014), the celestial sphere is divided into eighty-eight parts and their names are presented, in this case, in Latin. We considered the year 2014. 
names, the total number of nodes that were generated during the encoding of the interviews. Each free node represents a created code and the references are words and phrases taken from each interview, that is, in the case of Professor Leo, his interview generated forty-two nodes and one hundred and thirty-five references. The same process happened with the other teachers.

In all fourteen interviews, eighty-two codes were generated, which received one thousand, three hundred and eighteen references. It is the researcher himself who chooses, creates and interprets the words and phrases of the interviews for the elaboration of the codification.

The researcher thinks and arranges the data into codes. The codes are not structured randomly or improvised; they organized in accordance to the form provided in the coding tools available in WebQDA. ${ }^{2}$

In this first moment, the free node encoding system was used, among the available functionalities. With free nodes, the researcher has the freedom and flexibility to encode the data according to the research objective.

According to Table 2(a), four hundred and twenty-eight free nodes and one thousand three hundred and eighteen references were generated.

Considering the same table, with the hierarchy of references, that is, the interview from which the greatest number of words and phrases have been taken, we have the following situation:

The interval between the interviews with the highest number of references for the interview with the lowest number of references was about one hundred and thirty-eight, and sixty-one. In Table 2(b), a column (Order) was included that shows the sequence with which the interviews were performed. The interesting thing is that in the first two lines of this table, it is possible to verify that the greatest number of references extracted from the interviews refers to the interview number 1 and the interview number 14, that is, the first and the last interview conducted.

Table 3, shows that among the eighty-two codes produced during interview reading, the first thirty codes are those with the highest number of references.

The first five codes with the highest number of references are preparation for the teaching career; Strategies for dealing with room management; Potential and experience of the student; the research produced and used by the teacher. These represent approximately thirty-one percent of all references taken from teacher interviews.

In Table 4, all codes were classified into fifteen categories, in the WebQDA system. In addition to the free nodes, it is possible to encode the information in tree nodes. These tools allow the researcher to organize the collected information.

${ }^{2}$ Node is a clustered topic of ideas and can be assigned and defined according to the researcher's choices. It is a tool designated in WebQDA for interpretive coding. Nodes are divided into free nodes and tree nodes. Free nodes organize the clusters of ideas without defined hierarchical systems (the connection between nodes). Tree nodes allow hierarchy in nodes and sub nodes at the desired or required depth. Tree nodes organize clusters of ideas in a branched system, that is, in a hierarchical system with links between nodes. (WebQDA, 2013, software to support the qualitative analysis: user's manual, Esfera Crítica and University of Aveiro, Portugal). 
Table 2. (a) Coding system, (b) Reference hierarchy.

(a)

\begin{tabular}{lccc}
\hline & NAME & FREE NODES & REFERENCES \\
\hline $\mathbf{1}$ & Leo & 42 & 135 \\
$\mathbf{2}$ & Crux & 32 & 121 \\
$\mathbf{3}$ & Sagittarius & 27 & 63 \\
$\mathbf{4}$ & Gemini & 25 & 61 \\
$\mathbf{5}$ & Pyxis & 27 & 76 \\
$\mathbf{6}$ & Andromeda & 30 & 93 \\
$\mathbf{7}$ & Phoenix & 34 & 98 \\
$\mathbf{8}$ & Aries & 30 & 126 \\
$\mathbf{9}$ & Orion & 33 & 138 \\
$\mathbf{1 0}$ & Taurus & 32 & 68 \\
$\mathbf{1 1}$ & Capricornus & 30 & 82 \\
$\mathbf{1 2}$ & Pegasus & 25 & 61 \\
$\mathbf{1 3}$ & Draco & 32 & 110 \\
$\mathbf{1 4}$ & Aquila & 29 & 86 \\
& Total & 428 & 1318 \\
\hline
\end{tabular}

Source: Primary data.

(b)

\begin{tabular}{|c|c|c|c|c|}
\hline Number & NAME & INTERVIEW ORDER & FREE NODES & REFERÊNCE \\
\hline 1 & Orion & 14 & 33 & 138 \\
\hline 2 & Leo & 1 & 42 & 135 \\
\hline 3 & Aries & 4 & 30 & 126 \\
\hline 4 & Crux & 3 & 32 & 121 \\
\hline 5 & Draco & 7 & 32 & 110 \\
\hline 6 & Phoenix & 6 & 34 & 98 \\
\hline 7 & Andromeda & 2 & 30 & 93 \\
\hline 8 & Aquila & 5 & 29 & 86 \\
\hline 9 & Capricornus & 11 & 30 & 82 \\
\hline 10 & Pyxis & 13 & 27 & 76 \\
\hline 11 & Taurus & 12 & 32 & 68 \\
\hline 12 & Sagittarius & 10 & 27 & 63 \\
\hline 13 & Pegasus & 8 & 25 & 61 \\
\hline \multirow[t]{2}{*}{14} & Gemini & 9 & 25 & 61 \\
\hline & Total & & 428 & 1318 \\
\hline
\end{tabular}

Source: Primary Data.

Among the fifteen categories presented, ten categories were taken from the definition framework of the categories that make up the set of pedagogical knowledge of teachers (Shulman, 1987): Knowledge of content; General didactic knowledge; Curriculum knowledge; Didactic knowledge of content; Knowledge of students and their characteristics; Knowledge of educational contexts; Knowledge 
Table 3. Codes and references.

\begin{tabular}{|c|c|c|}
\hline NUMBER & CODE & REFERENCE \\
\hline 1 & Preparation for the teaching career & 100 \\
\hline 2 & Strategies for dealing with classroom management & 95 \\
\hline 3 & Student Potential and Experience & 77 \\
\hline 4 & Beginning of teaching career & 70 \\
\hline 5 & The research produced and used by the teacher & 62 \\
\hline 6 & Expected results & 61 \\
\hline 7 & Sharing values & 61 \\
\hline 8 & Didactic Transposition & 50 \\
\hline 9 & Teaching career phases & 48 \\
\hline 10 & Participation in the PPC discussions & 48 \\
\hline 11 & Course objectives information & 43 \\
\hline 12 & Relationship to teacher and student & 41 \\
\hline 13 & Knowledge about HEI & 35 \\
\hline 14 & Inspiration in other teachers & 35 \\
\hline 15 & Resource and infrastructure available & 35 \\
\hline 16 & Didactic culture & 31 \\
\hline 17 & Competence to teach & 25 \\
\hline 18 & Contents taught & 25 \\
\hline 19 & Connections & 22 \\
\hline 20 & Difficulty in applying the contents & 22 \\
\hline 21 & Passion to be a teacher & 19 \\
\hline 22 & Teaching career & 15 \\
\hline 23 & Initial difficulties & 15 \\
\hline 24 & Early career & 14 \\
\hline 25 & Teacher life & 13 \\
\hline 26 & Disciplines of pedagogical training & 12 \\
\hline 27 & Teacher educator & 12 \\
\hline 28 & The role of the teacher & 11 \\
\hline 29 & Motivation to continue your career & 11 \\
\hline 30 & Teaching time & 10 \\
\hline
\end{tabular}

Source: Primary data.

of purpose; Knowledge of objectives; Knowledge of values; Knowledge of philosophical foundations.

The other categories included were: The teaching career; Preparation for the teaching career-pedagogical training; Phases in the teaching career; Didactic culture and others.

These categories, included, contributed to the development of the research, according to the proposed research problem.

Table 5 shows the categories, codes, percentage of codes, reference and percentage of reference. 
Table 4. Categories, codes and references.

\begin{tabular}{cccc}
\hline NUMBERS & CATEGORIES (Tree nodes) & CÓDES & REFERÊNCE \\
\hline $\mathbf{1}$ & Teaching career & 26 & 250 \\
$\mathbf{2}$ & Teacher career preparation-pedagogical training & 9 & 159 \\
$\mathbf{3}$ & Knowledge of content & 7 & 92 \\
$\mathbf{4}$ & General didactic knowledge & 4 & 104 \\
$\mathbf{5}$ & Curriculum knowledge & 3 & 64 \\
$\mathbf{6}$ & Didactic knowledge of content & 1 & 51 \\
$\mathbf{7}$ & Knowledge of students and their characteristics & 14 & 162 \\
$\mathbf{8}$ & Knowledge of educational contexts & 3 & 84 \\
$\mathbf{9}$ & Knowledge of the purposes & 2 & 72 \\
$\mathbf{1 0}$ & Knowledge of objectives & 1 & 44 \\
$\mathbf{1 1}$ & Knowledge of values & 4 & 73 \\
$\mathbf{1 2}$ & Knowledge of the philosophical foundations & 3 & 71 \\
$\mathbf{1 3}$ & Phases in the teaching career & 1 & 49 \\
$\mathbf{1 4}$ & Didactic culture & 1 & 34 \\
$\mathbf{1 5}$ & Others & 3 & 9 \\
& TOTAL & 82 & 1318 \\
\hline
\end{tabular}

Source: Primary Data.

Table 5. Categories, codes, percentage of codes, reference and reference percentage.

\begin{tabular}{|c|c|c|c|c|}
\hline CATEGORIES (Tree Nodes) & CODES & \% CODES. & REFERENCE & \% REFER. \\
\hline Teaching career & 26 & 31.70 & 250 & 19.00 \\
\hline Knowledge of students and their characteristics & 14 & 17.00 & 162 & 12.30 \\
\hline Teacher career preparation-pedagogical training & 9 & 11.00 & 159 & 12.06 \\
\hline Content knowledge & 7 & 8.50 & 92 & 7.00 \\
\hline General didactic knowledge & 4 & 4.90 & 104 & 7.80 \\
\hline Knowledge of values & 4 & 4.90 & 73 & 5.54 \\
\hline Curriculum knowledge & 3 & 3.70 & 64 & 4.85 \\
\hline Knowledge of educational contexts & 3 & 3.70 & 84 & 6.37 \\
\hline Knowledge of the philosophical foundations & 3 & 3.70 & 71 & 5.38 \\
\hline Others & 3 & 3.70 & 9 & 0.70 \\
\hline Knowledge of the purposes & 2 & 2.43 & 72 & 5.46 \\
\hline Knowledge of objectives & 1 & 1.21 & 44 & 3.35 \\
\hline didactic content knowledge & 1 & 1.21 & 51 & 3.90 \\
\hline Phases in the teaching career & 1 & 1.21 & 49 & 3.71 \\
\hline Didactic Culture & 1 & 1.21 & 34 & 2.58 \\
\hline Total & 82 & $100 \%$ & 1318 & $100 \%$ \\
\hline
\end{tabular}

Source: Primary Data.

The categories were included according to the codes and in descending order. Then, with table this table, it is possible to verify that the career category has a per- 
centage of practically thirty-two percent of the total categories listed in this table.

Second, with seventeen percent, the category was the knowledge of the students and their characteristics. Coincidentally, the teaching career item had a total of two hundred and fifty references, being the most cited of the items in the table.

This first place in the table, both in relation to the code, as well as to the reference, may have occurred because it is the first topic of the interview. For this reason, teachers interviewed felt motivated and willing to share their experiences, such as the beginning of a teaching career, preparation for a teaching career, reporting a little of their history as a teacher and even remembering the beginning of their career In higher education.

In Table 6, it is possible to analyze, from the frequency of the words most cited in the interviews, some interesting points, such as, for example, the variation in the way these words are used by the interviewees.

As it can be seen in Table 6, among the fifteen words most cited in the interviews, they are all directly associated with the study object of the research.

The word teacher was the most mentioned, followed by the words knowledge, content, masters, discipline, career and again the word teachers, this time in the plural.

To elaborate this table we used the resource of most frequent words of the WebQDA. The thirty-four most frequent words in the fourteen interviews were related, with a minimum of eight letters, a criterion defined by us.

From the analysis and interpretation of the interview results, it was possible to identify that some teachers already thought about the teaching career in higher

Table 6. Frequency of words most cited in interviews.

\begin{tabular}{|c|c|c|c|}
\hline WORD & FREQUENCY & WORD & FREQUENCY \\
\hline Teacher & 782 & Learning & 87 \\
\hline Knowledge & 319 & Content & 86 \\
\hline Content & 298 & Curriculum & 85 \\
\hline Master's degree & 231 & Objective & 75 \\
\hline Discipline & 215 & Didactic & 74 \\
\hline Career & 183 & Develop & 73 \\
\hline Teachers & 182 & Goals & 73 \\
\hline Formation & 171 & Superior & 70 \\
\hline Undergraduate degree & 170 & Performance & 69 \\
\hline Doctorate degree & 157 & Evaluation & 67 \\
\hline Management & 148 & Problem & 65 \\
\hline Didactics & 139 & Teaching & 63 \\
\hline Research & 132 & Strategies & 63 \\
\hline University & 116 & Subjects & 62 \\
\hline Semester & 115 & Environment & 61 \\
\hline Process & 104 & Strategy & 61 \\
\hline Experience & 102 & Institution & 58 \\
\hline
\end{tabular}

Source: Primary Data. 
education from the beginning of the university formation or professional career. All the others ended up migrating to this area without having planned to start teaching.

In general, it is possible to contextualize this situation, at least in relation to our research, in which the majority of teachers started their teaching careers in higher education as a second option.

The decision to start a teaching career brings some interesting testimonials, and it is noted that teachers did not plan their careers as teachers in higher education. Nevertheless, in general, it happened almost automatically, motivated by different causes. Opportunities arose and teachers gradually engaged in higher education.

It is noticed in the interviewees' speeches a lack of planning for the teaching career, even so, nothing made these teachers unable to start a career in higher education.

When analyzing the answers of the fourteen professors interviewed, only two professors were categorical in the sense of having planned the teaching career.

Several teachers interviewed cited the passion in the teaching career.

They demonstrate passion for the teaching career, passion in being a university professor. This is enough to lead us to believe that even without having, at first, adequate planning or planning to pursue a teaching career in higher education, these teachers have engaged their career so that they can no longer move away from It They are passionate about what they do.

Regarding the passion for the teaching career in the area of management, or the passion to be a teacher, Simendinger et al. (2009) mention some important attributes of teachers who teach classes in business programs. Among these attributes, they are well prepared for class; Accessible to students; Have passion and enthusiasm for teaching; Organized and flexible. For Sié and Yakhlef (2009), teachers must be motivated by what they do and make every effort to achieve their goals.

The teacher's passion for education helps him sustain his efforts in difficult times in his teaching career. Having a passion for teaching is making a difference in the lives of students (Rampa, 2012).

Some teachers interviewed cited other teachers as a source of inspiration early in their teaching career. This is due, among other things, to the lack of adequate pedagogical training and the need for initial support at the beginning of the teaching career. Many of the interviewees ended up adopting some references they found in teachers they had in the past.

Timpson and Bendel-Simso (1996) and Juliatto (2013) state that one of the main functions of the teacher is the influence that he can exert on his students, inspiring them and motivating them to study. Bireaud (1995) refers to the principle of isomorphism, the student, will reproduce the pedagogical practices that he learned in the university with his trainers.

In relation to the preparation for the teaching career, this one, during the codification process with the WebQDA, was the code that gathered the largest number of references, considering all the interviews conducted.

Under the same topic of preparation for the teaching career, some teachers 
mentioned that they came to receive such preparation during the masters or even the doctorate. They also mentioned that they have obtained this preparation or improvement in LatoSensu programs, which has generally contributed positively. Some, however, felt that there were cases where these programs had a negative influence.

From the narratives, it can be observed that some of the interviewees had training for the teaching career during the master's degree. One of them recalls that during the undergraduate degree program in physical education, he had disciplines focused on teacher training and didactics, as well as in another form, known at the time by Scheme, when he also had the opportunity to participate in training of this type, focused on teaching.

The university teacher training is still very precarious. In Brazil, there is no tradition of teacher training for higher education (Joaquim, Vilas Boas, \& Carriei, 2013). This happens mostly in those cases where undergraduate programs undertaken are not the undergraduate education programs. Gray and Hoy (1989), apud Marcelo (1999: p. 248), make reference to the pedagogical training of teachers "[...] there has not been a tradition of professional training in higher education until now, and young teachers have always been Left alone, except perhaps a brief course of initiation".

Teacher training can be considered, as Marcelo (1999) argues, even as a counterpoint to a larger project that depends not only on financial resources, but also on processes involving several decision-making levels, the figure of the teacher mentor. The mentor is a teacher with teaching experience who accompanies a fresh teacher in higher education for a certain period of time. The knowledge of the mentor teacher is made available to the fresh teacher, contributing positively to his teacher training for higher education.

On the didactic knowledge of the content, teachers were asked how they do the didactic transposition, that is, how to make content into something that can be taught (Chevallard, 1991).

In this item, the answers were once again useful, which shows how this group of teachers, even without adequate pedagogical training, is prepared to deal with the contents of the curriculum.

The answers show that each teacher participating in the interview has used a variety of ways to make the content he/she teach more understandable to students, such as the use of case studies.

Next, we present the responses, which were based on the definition of the categories that make up the teachers' pedagogical know-how (Shulman, 1987).

Considering the framework of Shulman (1987), it was the content taught by the teachers. Among other things, the difficulties that teachers present to develop and apply the contents have arisen.

All teachers interviewed stated that they have no difficulty in applying or developing the contents they teach, which is mainly explained by the time they teach in higher education in their respective fields.

Lizzio, Wilson, \& Simons (2002), Entwistle, Mccune, \& Hounsell (2002), 
Mintzberg \& Gosling (2003), Handal, Wood, \& Muchatuta (2011), Juliatto (2013) and Duarte (2013) Students are negatively influenced when there is a poor perception about a particular teaching environment, especially when the teacher is not able to adequately transmit the contents, becoming only a replicator of the same contents.

This condition leads them to deal with their studies with superficiality, which will result in low educational achievement, sometimes close to no achievement at all.

Some respondents did very well in their answers to questions about the atmosphere in the classroom in relation to student performance.

According to Tardif (2000), teachers cannot be considered simple technicians who only dedicate themselves to apply knowledge produced by others. It is fundamental that in addition to the technical knowledge about certain content, the teacher knows how to manage his classroom, with the ultimate goal of obtaining the best result of his students. In order to make manage his/her classroom well, it is necessary that the teacher has an adequate pedagogical training.

When questioned about general didactic knowledge, they focused on strategies for creating effective learning, questioning the strategies used by the teacher with the goal of improving student learning.

In this sense, as presented previously, Chickering and Gamson (1987), Chickering (1999) presented the seven principles based on research on good pedagogical practice in American higher education institutions.

Other authors, such as Vaara and Fay (2012), Pfeffer and Fong (2002, 2004), Starkey, Hatchuel, \& Tempest (2004) have come to the conclusion that some studies on pedagogical practice used by teachers from several Business schools present themselves inadequately for the effective learning of future administrators.

Regarding the respondents, the answers obtained on this issue show the concern about the creation of strategies that contribute satisfactorily to student learning. They are aware of the need for further improvement in the teaching career.

For many teachers, this process of learning to work in practice, or groping, is a way of forging a didactic that will accompany them throughout their lives. Once again, the need for specific training for teaching in higher education.

For most teachers interviewed, the question of general didactic knowledge and strategies for creating effective learning is very latent. It is present and strong in the life of each teacher, which has contributed significantly to their respective performances as teachers, as well as to the learning of their students.

The main strategy of learning is to mobilize as much as possible the knowledge and experience of the individual to seek or create the coherent integration of ideas that supports understanding (Claxton, 2005). One of the fundamental elements in the teaching-learning process is the interaction of the teacher with the students. Knowing the student, his potentials and desires will definitely contribute to the improvement of his academic performance.

Students will have better performance as teachers use their most important attributes, as advocated by Centra (1979) and Dehler (2009), in relation to 
teachers who teach classes in business programs. These attributes are communication skills, favorable attitudes towards students, knowledge about the subject, flexibility, development of critical thinking with the student, interest of the teacher, among many others. In this relation, I would add the teachers' knowledge about the experiences of their students. We must always consider experience and practice as a way for students to develop their skills (Jonnaert et al., 2010).

With regard to student learning, they expect a pleasant teaching environment, it should be enjoyable. It should also bring the possibility of acceptance by teachers and other students. Certainly, this influences them in the sense of deepening the subjects studied. According to some authors, they will be more prone to study harder (Lizzio, Wilson, \& Simons, 2002; Entwistle, Mccune, \& Hounsell, 2002; Mintzberg \& Gosling, 2003; Handal, Wood, \& Muchatuta, 2011; Juliatto, 2013; Duarte, 2013; Mitchell \& Bradshaw, 2013).

When asked about the production of research and whether this production can influence the students "learning process, they were unanimous in saying that research has a significant influence on students" learning. This production gives more credibility to the teacher, enabling him to work with texts, as scientific articles, which are the result of his own research.

Meyers (2012) argues, as mentioned before, the importance of evaluating different factors that qualify the performance of teachers of business programs and that can influence the work of these teachers in the classroom. Twelve factors were identified, among them, the possibility of discussing research results during class. Therefore, it is important the generation of knowledge by the teachers who work in higher education.

Based on what stated above, it was possible to have a broad view of how the interviewees perceive their actions as teachers and those of other teachers.

The last issue of the interview dealt with the didactic culture, a subject defined by us.

Didactic culture is the pedagogical knowledge cultivated by the teacher of business administration programs throughout his teaching career. Therefore, it is associated with the technical knowledge acquired mainly during the academic training.

It aims at improving their teaching performance in the classroom and seeks to increase the learning process of the student, so that this student can become a transforming agent of society.

All questions addressed the topic of didactic culture. The last question made it possible for us to hear from teachers what their perception of this term is in a question.

From the fourteen interviewed teachers, it was possible to gather, through the data collected, that most of them, eleven teachers, answered the question about didactic culture very closely to the definition that was developed during this research.

From the teachers' replies, phrases or expressions represent in a very assertive way the meaning of didactic culture, such as "[...] a set of norms, a set of skills, competencies, Autonomous", “... a set of habits and values that are being forged, 
are being built over time", $[\ldots]$ they are coined by experience and by the person's experience, reinventing the "If you find your way, this is a way you will find, you will improve", "[...] you have a culture of methods, a culture of didactics", "How can I find mechanisms to make people understand certain concepts", "And gradually, even if you do not have a pedagogical background, you begin to realize", "It seems like it works, it does not seem to work, it is good, it is not good", "And then you are creating some conscious rules or not about what works", "Didactic culture is how you build the Way of transmitting things within the classroom, I bring the experience of my other teachers", "[...] have to water it, otherwise the plant dies", "The strategies you use, how you are relating with the students".

Even though these teachers did not have a pedagogical training covering some aspects of teacher training, in their answers, it can be seen that they demonstrate a certain alignment between what they do and develop with the concept of didactic culture, a concept that seems to be intrinsic to the one who exercises the teaching career.

The answers also show us that even without such training, teachers have developed during their teaching careers certain competences that enable them to teach, which makes them fulfill their roles in teaching. Thus, they can contribute significantly to the learning of their students.

As Huberman (1998) teaches, apud Tardif (2000: p. 13), Even today, most teachers learn to work in the classroom, groping, by trial and error. It's the phase called exploration. For our teachers, this process of learning to work practicing is a way of forging useful didactics that will accompany them throughout their lives.

Regarding the responses of teachers when questioned about didactic culture, there is a certain adherence to what Chickering and Gamson (1987), Chickering (1999) reported in their research. It was possible to raise with these answers some important aspects of the understanding of these teachers about didactic culture.

For the group of teachers interviewed and who answered about didactic culture, they seem well articulated in their pedagogical practice. They adopt dynamic and participatory contents that end up influencing classroom management. This attitude generates benefits, such as turning your classroom into a more current, contextualized and dynamic teaching practice.

Finally, from the analysis and interpretation of information and considering the categories that form the framework of the categories that make up the set of pedagogical knowledge of teachers (Shulman, 1987), we elaborate a new framework: The categories that form the didactic culture.

In relation to the names used in the new framework, we still use the framework of Shulman (1987). Two new categories were added: career entry and preparation for the teaching career, topics that also included the in-depth interview.

It is worth mentioning that this new framework does not specifically address teacher knowledge for business administration teachers who act as teachers in higher education, but instead, some relevant points of the didactic culture.

This table summarizes the main points of the data collection from the analysis and interpretation of the results [Table 7]. 
Table 7. Categories that make up the didactic culture.

\begin{tabular}{|c|c|}
\hline \multicolumn{2}{|r|}{ Categories that make up the didactic culture } \\
\hline CATEGORY & CATEGORY DESCRIPTION \\
\hline Career entry & The story of how the teacher began his teaching career in higher education and the choice of a teaching career. \\
\hline $\begin{array}{l}\text { Preparing for the } \\
\text { Teaching Career }\end{array}$ & Participation in pedagogical training courses during the master's and doctoral studies, or in other opportunities. \\
\hline Educational Strategies & $\begin{array}{l}\text { Strategies for creating appropriate learning in an environment conducive to the teaching and learning process. The } \\
\text { teacher as mediator in this process, motivating, interacting and creating strategies to deal with classroom } \\
\text { management. }\end{array}$ \\
\hline $\begin{array}{l}\text { Didactic Transposition } \\
\quad \text { (Chevallard, 1991) }\end{array}$ & How to make content understandable to students. \\
\hline $\begin{array}{l}\text { Knowledge of Curriculum } \\
\text { program }\end{array}$ & $\begin{array}{l}\text { The knowledge the teacher has about the curriculum of the business administration program in its entirety: menus, } \\
\text { objectives, assessment systems, student profile, expected student competencies, among others. }\end{array}$ \\
\hline Student Potential & $\begin{array}{c}\text { Know the students and their characteristics. The experiences of students taken into account in the classroom, for the } \\
\text { planning and execution of academic activities. }\end{array}$ \\
\hline Institutional Values & $\begin{array}{l}\text { Knowledge of the values of the institution of higher education to which the teacher is affiliated, considering these } \\
\text { values as guides for the development of academic activities and their use in favor of the teaching and learning process. }\end{array}$ \\
\hline
\end{tabular}

Source: The author.

Regarding the pedagogical strategies, we refer to the discussion forums in the classroom, flipped classroom, the technique in which students interact with each other based on their professional experiences, peer tutoring, the teacher using his/her Professional experience to contextualize a certain subject, the stimulation of student participation and the teacher's own motivation in the classroom from a more learning-friendly environment.

Regarding the didactic transposition (Chevallard, 1991), the interviewed teachers use different ways to make the contents understandable for the students, but especially the case study.

\section{Conclusion}

With regard to the development of didactic culture by the teachers interviewed, even though these teachers did not have an adequate pedagogical training to be teachers, it was possible to identify in the answers a very strong alignment between what they do and the concept that was created by us, the Didactic culture. This reveals that, even without such training, these teachers have developed certain competencies throughout their teaching careers, which enabled them to teach in higher education. Thus, they have become fit for the fulfillment of their functions, which contributes significantly to the learning of their students.

Due to the lack of adequate pedagogical training, this process of learning to work in practice for these teachers ends up being a way of creating a didactic culture and it will be present throughout their teaching careers.

Another important point is that the didactic culture of these teachers, besides being acquired over the years in the teaching career in higher education, has in its constitution information acquired by the teacher himself, as was seen previously. This information corresponds to behaviors or attitudes observed or copied from other teachers, especially when the interviewees were in the profes- 
sional training phase, either at the undergraduate, master's or doctoral levels.

Regarding content knowledge, which is one of the selected categories of the Shulman framework, all teachers interviewed stated that they did not have difficulty in applying or developing the contents they teach, which is evidenced mainly by the time these teachers have in teaching higher education, in their respective fields.

On the general didactic knowledge, which includes the strategies for creating effective learning, or the strategies used by the teacher to improve student learning, the answers obtained in this question showed the concern of all teachers with the creation of strategies that contribute in a satisfactory way to student learning.

Among the strategies used by teachers, the following can be mentioned: the discussion forums in the classroom; flipped classroom, which is the technique in which students interact with each other from their professional experiences; peer tutoring; the teacher who uses his professional experience to contextualize a certain subject; the encouragement of student participation; the teacher's own motivation in the classroom. All this so that it is seen and recognized by the students as a facilitator in the teaching and learning process.

It was also observed that the teachers studied are able to develop and use strategies to encourage student-teacher contact; encourage cooperation among students; encourage active learning; give immediate feedback to students; emphasize time dedicated to each task; communicate with high expectations about results; respect the various talents in the classroom and their learning specifics.

On the didactic knowledge of the contents, the question addressed was how the teacher does didactic transposition.

It was verified, then, that all the interviewees make use of different ways to turn the contents understandable for the students, but, especially, the case study was highlighted.

Case studies encourage student engagement. They get involved, interact with each other and not just read the material and analyze what can be done. They also make decisions and observe the results of decisions that have been made.

With the student knowledge category and its characteristics, it was possible to gather very relevant information about the students. All respondents were unanimous in responding to the importance of engaging students in class.

One of the fundamental elements in the teaching and learning process is the teacher's interaction with his students. Knowing the student and their potentials will definitely contribute to the improvement of academic performance.

Based on the answers on the other topics, knowledge educational context, knowledge of the objectives, knowledge of the values, knowledge of the philosophical foundations, it was possible to raise not only the involvement in academic processes, but also their commitment in various subjects.

When teachers were asked about the beginning of their teaching careers in higher education, it was possible to hear interesting stories. Many of them had very peculiar situations about entering the teaching career. 
With the exception of one teacher, who attended a program for primary teaching in high school and two others who had the influence of some professors and because of the functions previously held in the teaching career, the other interviewees started their teaching career in higher education for very different reasons.

The vast majority, however, did not focus on becoming a teacher. In general, there was no planning for the beginning of the teaching career for higher education.

Regarding the preparation for teaching career, almost all interviewed teachers have undergone some form of training. This occurred mainly during the masters, in some cases, beyond the master's degree, in the doctoral program.

It is interesting to note that some of these teachers reported some disappointing experiences regarding teacher training. They did not realize anything positive about this training. On the contrary, they only pointed out negative aspects.

On the other hand, several teachers referred to the passion for their teaching career in higher education. This passion helps the teacher to sustain his efforts in difficult times. Having a passion for teaching is making a difference in the lives of students.

The interview also pointed out a concern that teachers have about seeking training programs for the teaching career. They seek to fit properly in their specific roles in teaching. To this end, they seek adequate training to improve their pedagogical practice and ways to become more important influencers in the teaching and learning process.

Considering the analysis and interpretation of the information collected during the interviews, it is possible to notice that all teachers interviewed during the research have a didactic culture of their own, which was developed during their respective teaching careers.

Based on the analysis and interpretation of the teachers' statements, we assume that the didactic culture influences the teaching activity of the teachers of the business administration program, which happens as teachers develop and implement activities related to the improvement of the teaching and learning process.

\section{References}

Altet, M. (1994). La formation professionelle des enseignants. Paris: PUF.

Anderson, K., \& Miller, E. D. (1997). Gender and Student Evaluations of Teaching. Political Science and Politics, 30, 216-219. https://doi.org/10.1017/S1049096500043407

Bardin, L. (2013). The Content Analysis, Collection Quadrige. Paris: PUF.

Bireaud, A. (1995). Osmétodospedagógicos no ensino superior. Porto: Porto Editora.

Cavanagh, R. F., \& Waugh, R. F. (2004). Secondary School Renewal: The Effect of Classroom Learning Culture on Educational Outcomes. Learning Environments Research, 7, 245-2694. https://doi.org/10.1007/s10984-004-3296-5

Centra, J. A. (1979). Determining Faculty Effectiveness: Assessing Teaching, Research, and Service for Personnel Decisions and Improvement. San Francisco, CA: Jossey-Bass 
Publications.

Cheng, Y. C. (1993). Profiles of Organizational Culture and Effective School. School Effectiveness and School Improvement, 4, 85-110. https://doi.org/10.1080/0924345930040201

Chevallard, Y. (1991). La transposición didáctica: Del saber sabio al saber enseñado. Argentina: La Pensée Sauvage.

Chia, R. (1996). Teaching Paradigm Shifting in Management Education: University Business Schools and the Entrepreneurial Imagination. Journal of Management Studies, 33, 409-428. https://doi.org/10.1111/j.1467-6486.1996.tb00162.x

Chickering, A. W. (1999). Development and Adaptations of the Seven Principles for Good Practice in Undergraduate Education. New Directions for Teaching and Learning, 1999, 75-81. https://doi.org/10.1002/tl.8006

Chickering, A. W., \& Gamson, Z. F. (1987). Seven Principles for Good Practice in Undergraduate Education. The Wingspread Journal, 9, 1-10.

Chong, S. (2014). Academic Quality Management in Teacher Education: A Singapore Perspective. Academic Quality Management, 22, 53-64. https://doi.org/10.1108/qae-05-2012-0023

Claxton, G. (2005). The Challenge of Lifelong Learning. Porto Alegre: Artmed.

Cochran-Smith, M. (2005). The New Teacher Education: For Better or for Worse? Educational Researcher, 34, 3-17. https://doi.org/10.3102/0013189X034007003

Collis, J., \& Hussey, R. (2005). Business Research: A Practical Guide for Undergraduate and Postgraduate Students (2nd ed.). Porto Alegre: Bookman.

Dehler, G. E. (2009). Prospects and Possibilities of Critical Management Education: Critical Beings and a Pedagogy of Critical Action. Management Learning, 40, 31-49. https://doi.org/10.1177/1350507608099312

Díaz-Méndez, M., \& Gummesson, E. (2012). Value Co-Creation and University Teaching Quality: Consequences for the European Higher Education Area (EHEA). Journal of Service Management, 23, 571-592. https://doi.org/10.1108/09564231211260422

Duarte, F. P. (2013). Conceptions of Good Teaching by Good Teachers: Case Studies from an Australian University. Journal of University Teaching \& Learning Practice, 10, Article 5.

Entwistle, N., McCune, V., \& Hounselll, J. (2002). Approaches to Studying and Perceptions of University Teaching-Learning Environments: Concepts, Measures and Preliminar Findings. Occasional Report, Enhancing Teaching-Learning Environments in Undergraduate Courses Project, Higher and Community Education, School of Education, University of Edinburgh.

Feldman, K. A., \& Paulsen, M. (1999). Faculty Motivation: The Role of a Supportive Teaching Culture. New Direction for Teaching and Learning, 1999, 69-78. https://doi.org/10.1002/tl.7807

Gauthier, C. et al. (1997). Pour unethéorie de la pédagogie. Sainte-Foy: Université Laval.

Halévy, M. (2008). L’Âge de la connaissance: Principes et reflexionssur la révolutionnoétique au 21 èmesiécle. São Paulo: Unesp.

Handal, B., Wood, L., \& Muchatuta, M. (2011). Students' Expectations of Teaching: The Business, Accounting and Economics Experience. e-Journal of Business Education \& Scholarship of Teaching, 5, 1-17.

Hanushek, E. A. (2002). Teacher Quality. In L. T. Izumi, \& W. Evers (Eds.)., Teacher Quality (pp. 1-12). Palo Alto, CA: Hoover Press.

Huberman, M. (2007). O ciclo de vidaprofissional dos professores. In A. Nóvoa (Org.), 
Vida de professors (2nd ed., pp. 31-61). Porto, Portugal: Porto Editora.

Imbernón, F. (1994). La Formación del profesorado: Papeles de pedagogía. Barcelona, España: Paidós.

Joaquim, N. F., Vilas Boas, A., \& Carrieri, P. (2013). Teaching Internship: Professional Training, Preparation for Teaching or Precarious Teaching? Educação e Pesquisa, São Paulo, 39, 351-365.

Jonnaert, P., Ettayebi, M., \& Defise, R. (2010). Curriculum and Skills. Porto Alegre: Artmed.

Juliatto, C. I. (2013). From Teacher to Teacher. Curitiba: Champagnat.

Lizzio, A., Wilson, K. \& Simons, R. (2002). University Students' Perceptions of the Learning Environment and Academic Outcomes: Implications for Theory and Practice. Studies in Higher Education, 27, 27-52. https://doi.org/10.1080/03075070120099359

Marcelo, G. C. (1999). Formação de professores: Para umamudançaeducativa. Porto, Portugal: Porto Editora.

Meyers, M. (2012). How Business Faculty Evaluate Teaching Effectiveness. Proceedings of Academy of Marketing Studies, 17, 17-20.

Mintzberg, H., \& Gosling. (2003). Educating Administrators across Borders. RAE-SP, 43, $29-43$.

Mitchell, M., \& Catherine P. (2013). Examining Classroom Influences on Student Perceptions of School Climate: The Role of Classroom Management and Exclusionary Discipline Strategies. Journal of School Psychology, 51, 599-610.

Morgan, G. (1996). Images of Organization. São Paulo: Atlas.

Pennings, J. M. et al. (2014). Real-Time Teacher-Student Interactions: A Dynamic Systems Approach. Teaching and Teacher Education, 37, 183-193.

Pfeffer, J., \& Fong, C. T. (2004). The Business School "Business": Some Lessons from the US Experience. Journal of Management Studies, 41, 1501-1520.

https://doi.org/10.1111/j.1467-6486.2004.00484.x

Pfeffer, J., \& Fong, C. T. (2002). The End of Business Schools? Less Success than Meets the Eye. Academy of Management Learning \& Education, 1, 1560-1582.

Philipp, A., \& Kunter, M. (2013). How Do Teachers Spend Their Time? As Study on Teachers' Strategies of Selection, Optimization, and Compensation over Their Career Cycle. Teaching and Teacher Education, 35, 1-12.

Pimenta, S. G., \& Anastasiou, C. (2012). Teaching in Higher Education (4th ed.). São Paulo: Cortez.

Rampa, H. (2012). Passion for Teaching: A Qualitative Study. Procedia-Social and Behavioral Sciences, 47, 1281-1285.

Reid, J.-A. (2011). A Practice Turn for Teacher Education? Asia-Pacific Journal of Teacher Education, 39, 293-310. https://doi.org/10.1080/1359866X.2011.614688

Robinson, E., \& Hope, C. (2013). Teaching in Higher Education: Is There a Need for Training in Pedagogy in Graduate Degree Programs? Research in Higher Education Journal, 2, 1-11.

Seidman, I. (1998). Interviewing as Qualitative Research: A Guide for Researchers in Education and the Social Sciences. New York: Teachers College Press.

Shulman, L. S. (1987). Knowledge and Teaching: Foundations of the New Reform. Harvard Educational Review, 57, 1-23. https://doi.org/10.17763/haer.57.1.j463w79r56455411

Sié, L., \& Yakhlef, A. (2009). Passion and Expertise Knowledge Transfer. Journal of 
Knowledge Management, 13, 175-186. https://doi.org/10.1108/13673270910971914

Simendinger, E.et al. (2009). Attributes of Effective Business Teachers. Academy of Education Leadership Journal, 13, 107-130.

Solomon, R. C. (1992). Ethics and Excellence: Cooperation and Integrity in Business. New York: Oxford University Press.

Starkey, K., Hatchuel, A., \& Tempest, S. (2004). Rethinking the Business School. Journal of Management Studies, 41, 1521-1531. https://doi.org/10.1111/j.1467-6486.2004.00485.x

Tardif, M. (2000). Professional Knowledge of Teachers and University Knowledge. Revista Brasileira de Educação, São Paulo, 13, 5-24.

Tardif, M., \& Lessard, C. (2009). La profession d'ensignat. Petrópolis, RJ: Vozes.

Timpson, W. M., \& Bendel-Simso, P. (1996). Concepts and Choices for Teaching: Meeting the Challenges in Higher Education. Madison, WI: Magna Publications, Inc.

Vaara, E., \& Fay, E. (2012). Reproduction and Change on the Global Scale: A Bourdieusian Perspective on Management Education. Journal of Management Studies, 49, 1023-1051. https://doi.org/10.1111/j.1467-6486.2012.01049.x

WebQDA (2013). Qualitative Analysis Support Software. Portugal: Esfera Crítica e Universidade de Aveiro.

Williams, R. (2000). Culture. São Paulo: Paz e Terra.

Zeichner, K., Payne, K. A., \& Brayko, K. (2015). Democratizing Teacher Education. Journal of Teacher Education, 66, 122-135. https://doi.org/10.1177/0022487114560908

Submit or recommend next manuscript to SCIRP and we will provide best service for you:

Accepting pre-submission inquiries through Email, Facebook, LinkedIn, Twitter, etc. A wide selection of journals (inclusive of 9 subjects, more than 200 journals)

Providing 24-hour high-quality service

User-friendly online submission system

Fair and swift peer-review system

Efficient typesetting and proofreading procedure

Display of the result of downloads and visits, as well as the number of cited articles

Maximum dissemination of your research work

Submit your manuscript at: http://papersubmission.scirp.org/

Or contact ce@scirp.org 